Jurnal ASPIKOM, Vol. 7, No. 1, January 2022, pp. 16-31

P-ISSN: 2087-0442, E-ISSN: 2548-8309

DOI: http://dx.doi.org/10.24329/aspikom.v7i1.1017

\title{
Omnibus Law Discourse on Television: Support Elite or Public?
}

\author{
Hedi Pudjo Santosa ${ }^{1}$, Nurul Hasfi ${ }^{2 *}$, Triyono Lukmantoro ${ }^{3}$, Himmatul Ulya ${ }^{4}$, \\ Yofiendi Indah Indainanto 5 \\ ${ }^{1,2,3}$ Communication Department, Universitas Diponegoro, Jawa Tengah, Indonesia \\ ${ }^{4}$ Freelance Researcher, Magister of Communication Department, Universitas \\ Diponegoro, Jawa Tengah, Indonesia \\ ${ }^{5}$ Communication Department, Universitas Semarang, Jawa Tengah, Indonesia \\ *Corresponding author, e-mail: nurul.hasfi@live.undip.ac.id
}

\begin{abstract}
The mass media construct discourses with major impact on the formation of public opinion. This study identifies mass media discourse of the Job Creation Law produced in the 22 television dialogue programs aired by TV One, Metro TV, Kompas TV, and CNN Indonesia. By focusing on indicators of discourses, sources, and duration of speakings this study finds the dominant discourse of positive sentiment towards the Job Creation Law - which is mainly brought by the government elite and businessmen - namely economic improvement and investment. In contrary, television program shaped negatif sentiment of the Law in narrower space - which was brought mainly by activists, academics and laborers - including the Job Creation Law disserve labours, endangers the environment and sighned in unprocerudal mecanism. The data shows that the television dialogue has provide more space for the elite than the public in discussing the controversial issue of the Job Creation Law.
\end{abstract}

Keywords: Analysis Conversation; Discourse; Omnibus Law; Television

\begin{abstract}
Abstrak
Media massa mampu membangun wacana yang berdampak besar dalam pembentukan opini publik. Penelitian ini mengidentifikasi bagaimana media massa membangun wacana UU Cipta Kerja. Penelitian ini menggunakan Analisis Conversation (AC) untuk mengidentifikasi teks yang diproduksi 22 program dialog televisi yang secara khusus membahas Omnibus Law di empat stasiun televisi meliputi TV One, Metro TV, Kompas TV, dan CNN Indonesia. Dengan berfokus pada indikator agenda, narasumber, dan durasi bicara serta merujuk pada konsep teks televisi sebagai wacana, penelitian ini menemukan wacana dominan yang terbagun lebih mengarah pada sentiment positif terhadap UU Cipta kerja yang terutama dibawa elit pemerintah dan pengusaha yakni peningkatan ekonomi dan investasi. Sebaliknya, wacana bersentimen negatif dengan ruang lebih sempit dibawa teutama oleh aktivis, akademisi dan buruh diantaranya UU Cipta kerja tidak ramah pekerja, membahayakan lingkungan dan cacat prosedur. Data menunjukkan dialog televisi memberikan ruang lebih pada elite daripada publik dalam membicarakan isu konstroversial UU Cipta Kerja.
\end{abstract}

Kata Kunci: Analisis Wacana Perbincangan; Wacana; Omnibus Law; Televisi 


\section{Introduction}

The government's move to propose the Omnibus Law (OL) bill on job creation has generated various responses, ranging from rejection among the working-class community to getting support from employers' groups. The process of drafting the Job Creation Law, which was processed quickly and with minimal public participation, was deemed unfavorable to the working group and led to various objections that led to mass actions and debates in the media discussion room. Each opposing camp continues to speak in favor of its interests.

The emergence of the concept of The Omnibus Law originated from a speech by President Joko Widodo (Jokowi) which referred to the merging of the Taxation Law, Job Creation, and the empowerment of Micro, Small and Medium Enterprises (MSMEs) into one (Arnani, 2020). The term Omnibus is grammatically derived from the Latin, meaning "for all" (Toruan, 2017). In Black's Law Dictionary (1990), Omnibus Law is for all/all; contains two or more stand-alone items, often used in bills consisting of more than one general subject(Hantoro, 2019). This means that the Omnibus Law is a legal concept used for several regulations, including the Job Creation Law. The media's involvement in providing an understanding of OL becomes very important to provide an ideal picture of OL in society.

The context of the debate about the work creation law is divided into two stages: first, drafting laws at the executive level and ratifying at the legislative level. The media took the role of raising the issue of the Job Creation Law into topics of discussion that presented various sources from opposing camps. Television has a broad influence on the audience, making the issue of the Job Creation Law the main focus presented in the discussion room from groups with different views on the Job Creation Law to influence public opinion. Studies conducted by www.remotivi.or.id, (2020) on five online media, namely Kompas, Media Indonesia, CNN, Liputan 6, and Republika, show that the Job Creation Law tends to be reported positively (52\%). Of the five media, only Kompas gave more room for OL's rejection, namely (22.9\%), while the four media were no more than $17.5 \%$. More resource persons were presented from those who supported, namely, the government $(50.8 \%)$ and parliament $(15.8 \%)$, while only a few groups $(6.5 \%)$. This means that the media gives more space to those who support the Job Creation Law than giving portions to those against it.

The main fact that television media builds discourse based on media interests cannot be separated from ownership and media ideology that will reflect the discourse displayed. The media influences the constructed image of reality, so not all of the reality is displayed. Only based on the media's interests (ownership and ideology) can one reflect reality (Hajad, 2018; Musfialdy, 2019; Catrina, 2014). This means that the discourse displayed on the Job Creation Law is very dependent on the interests of the media. This influence makes the discourses of marginalized groups have a different place in media.

Disputes about the discourse of support and rejection cannot be separated from the legal substance, which is considered to cause problems. The application of the Job Creation Law is not balanced with the substance of regulations that can avoid conflicts, especially regarding workers' rights (Matompo \& Izziyana, 2020). The Job Creation Act only addresses gradual regulatory problems, such as regulatory compaction. However, in its application, the Job Creation Law must comply with the principles of transparency, participation, and accountability (Son, 2020). Media Television then questioned the problem to carry out discourse. Media that have a high interest in the 
news, such as Metro TV, TVOne, Kompas TV, and CNN Indonesia, have made the issue of the Job Creation Law the main topic.

The four media presented the issue of the Job Creation Law into several program programs with different packaging and duration. This article aims to explore discourse contradictions, which indicate the occurrence of rejection and support for the Job Creation Law in four television media, through a discourse analysis approach to conversations. Discourse analysis is used by using conversation analysis (conversation) tradition. According to Gill (2007), the tradition of discourse analysis, which involves speech-act theory, ethnomethodology, and conversation analysis, calls the function or action of the discourse orientation more focused on the discourse focus shown and seen details of organizing discourse texts in social interaction rather than connecting or representing reality (Nasrulah, 2020). This tradition is used to answer the research question of how discourse contradictions occur in television media texts and the position of each actor in the discourse displayed.

This research strengthens the discussion about the role of mass media as a means of political communication and the formation of public opinion (Santosa, 2017; Wulandari, 2016; Ayish, 2002). If the previous research looked at how television, especially news, builds an agenda and discourse, this research has a dialogue program as its object. The object of the program dialogue research was chosen because it is certain that it will present various parties who have competence in this issue.

However, apart from wanting to confirm the role of the mass media in facilitating public opinion and political communication, the researcher also focuses on the big issue brought up, namely the narrative of the Job Creation Law or the Omnibus Law, which has become controversial in Indonesian society. Most of the research that has been done has focused on how narrative develops on the internet, such as Twitter or more about the legal side (Febriansyah \& Muksin, 2021; Matompo \& Izziyana, 2020; Son, 2020). On social media, discussions about omnibus law are colored by undemocratic conversations such as the emergence of hoaxes and efforts to lead mass opinion by the elite. In this article, the researcher assumes that the mass media, namely television, which in fact has the principles of objectivity and factuality, should ignite a more democratic space in developing this issue.

\section{Method}

To see the text of the conflicting discourse on the Job Creation Act, this study uses the method of conversational discourse analysis (conversation analysis). According to Charles Antaki (2008), conversation analysis (CA) is one of the methods in discourse analysis that sees social action achieved through the media of conversation in interaction. The emergence of CA to focus interest in unpacking the text by starting to reveal the act of conversation. According to Antaki (2008), CA uses four criteria: finding the main data, compiling the text together, paying attention to the non-literal meaning of the text, and identifying social actions. CA wants to get closer to understanding speech without imposing interpretations of motives, thereby emphasizing the 'what' and 'how' of the inner actor.

Methodological features of $\mathrm{CA}$ is collecting data about naturally occurring interactions. Data collection can be done using a video or audio recorder to be transcribed to be analyzed in detail about the design, exchange, and coordination of actions in interactions (Hutchby, 2019). Conversation in interaction is considered a systematic process, has a structure, and design refers to the relationship between 
actions. CA tries to capture what is said and how it is said, so a series of symbols is used to capture the discourse of the pronunciation of words (Woffitt, 2005).

The steps for text analysis from CA are, first, by selecting videos on four national television stations, each of which has a duration of approximately 3 hours, namely Metro TV (6 shows), TV One (10 programs), Kompas TV (2 shows), and CNN Indonesia (4 events). The four television stations were chosen because they have a high intensity of reporting from the initial planning process, discussion of drafts, ratification, and formation of derivative regulations. There were 22 dialogue programs analyzed, with dialogue criteria involving more than two sources, namely talk shows, news programs, and editorial reviews. Video data is taken from the official Youtube of each television station. The second step is to watch the video to see what discourses each media displays and write down the important points of the conversation. Third, enter the text of discourse points into coding based on the dominant topic displayed by the media. Fourth, the dominant topic coding is used to analyze each television media regarding the discourse on the Job Creation Law.

\section{Results and Discussion}

The mass media have a significant role in shaping public discourse. As Fairclough argues, discourse is a regulated practice in which a number of statements can or may be presented. Discourse, in this case, can be seen as a set of rules and procedures for the emergence of certain discourses. Broadly speaking, Fairclough put forward three rules into forming a discourse, namely, what object of discourse is being discussed. Second, who or which party is allowed to speak. Third, what concepts or theories are accepted as knowledge in the discourse? (Fairclough, 1995). In practice, the three discourse arrangements as a whole are always used by the mass media. Thus, the mass media consciously created the mechanism of discourse formation.

The analysis conducted on the dialogue about the Job Creation Bill or the Omnibus Law on four national television stations shows that the media carry out contradictory discourses. There are two major conflicting discourses, namely the groups that support and reject the ratification of the Cipataker Bill. This article shows that the media has a huge role in exposing actors or groups who support the Job Creation Bill compared to groups that reject it. High exposure is strongly influenced by ownership, as can be seen from the duration of the speech and the number of source persons.

\section{Media Discourse Contradictions}

Television has a very important influence in conveying information, which forms a discourse that can influence. The nature of television which can present visual and audio power, makes the effects that have a broad impact on the audience. This cannot be separated from the media that provide freedom in conveying information. According to McQuail (2000), one of the benchmarks in assessing media freedom is the policy of an active and critical news editor in conveying news and opinions (something that is desired but is optional) (Morissan, 2015). This means that the media has a role in determining the issues to be raised through editorial mechanisms, such as selecting sources, highlighting, and duration of time. Through this process, there will be conflicts between various discourses circulating in public. The four television stations have different interests in issues that allow each discourse to be presented in different forms and emphasis. The practice of conflicting discourse between the media through the placement of sources will cause bias, making it difficult to understand which discourse 
is considered correct.

The results of the analysis of 22 dialogue programs that were researched on four national television stations showed that there were conflicting discourses displayed by the media in reporting the ratification of the Job Creation Law, overlapping laws, employment, use of demography, disinformation issues, and political issues. The eight topics became conflicting discourses between support and opposition groups in the ratification of the Job Creation Law.

First, the topic of improving the economy became a strong reason to immediately ratify the Job Creation Law, which was supported by the government and employers. The step to ratify the law is taken because the government is trying to support changes in the economic structure. The government tries to encourage the country's economic growth, which is expected to grow to 5.7-6.0\% (www.tempo.co) from the previous growth of only $2.9 \%$ in the first quarter of 2020 (www.bps.go.id). So problems such as unemployment increasing every year and becoming a burden on the government can be overcome by the existence of the Job Creation Act. Improving the country's economy has become the government's obsession with equalizing Indonesia with other developed countries in Asia. This is because this country has a wealth of natural resources (SDA) and a demographic bonus as the fourth most populous country to support economic growth through various potentials possessed by Indonesia to attract foreign investors.

On the other hand, the opposing group, which workers dominate, considers the Job Creation Act only order from employers and places greater importance on capital owners than workers. This means that the Job Creation Law only cares about business people, expanding and exploiting excessively the human resource with the government's permission. Also, the drafting of the Employment Creation Law did not involve workers and significantly reduced the employment law, which was predicted to harm workers' rights.

Second, the topic of investment, both groups, both supporters and opponents of the Job Creation Law, have a common understanding, namely agreeing to the existence of a law that can attract investors to encourage economic growth and overcome economic problems in Indonesia, including unemployment. However, the two have quite a big difference in views. Supporters of the Job Creation Law believe that investment improvement must involve trimming business regulations and licensing to attract an investment climate. So that the government's efforts to reduce various laws into one carriage in the Job Creation Act become the final solution to attract investors, especially foreign investors.

On the other hand, the contra group considers cutting business licenses for domestic investors to extract natural resources (SDA), which was previously limited by several other regulations contained in regional government regulations and related ministries. According to groups opposed to the job creation law, foreign investors did not complain much about the previous law because their business licensing was in the manufacturing, services, and garment sectors, which did not make much use of natural resources. Meanwhile, domestic investors dominate the business in natural resource dredgings, such as mining and oil palm plantations.

Third, discussion of the bill. The counter-job creation group consisting of workers, academics, and the opposition parliament were not involved in discussing the job creation bill. These groups include labor unions, local governments (Pemda), and several members of the DPR RI, especially from the faction against the Job Creation Law. The labor group views that the government does not prioritize public participation 
in the drafting process, so it is considered not to put the interests of the workers first. In line with that, the West Java regional government considers it very important to involve the regional government in managing regional interests. Without participation, the draft to be passed is considered undemocratic and more burdensome on investment licensing. Meanwhile, several members of the DPR RI who are against Job Creation are from the government's opposition party faction, not much involved in drafting. Even articles that have previously been approved for deletion reappear in the Job Creation Bill ratified.

Meanwhile, as one of the supporters of the Job Creation Law, the government argues that all group interests have been involved in the discussion of the Job Creation Bill. This means that the draft job creation law has covered all group interests and is fair. As a support group, the central government considers that the preparation of the Job Creation Law has involved various parties in the drafting process. However, not all interests can be included. In addition, groups supporting the job creation bill also argued that all interests, including the interests of the opposition faction of the DPR RI, had been appropriately accommodated and even claimed that all members of the DPR agreed with the job creation bill.

Fourth, overlapping laws. The Job Creation Act facilitates bureaucratic licensing, regulatory efficiency, and support MSME businesses. This claim from the government is expected to improve the community's economy because the regulations are easy and not multilevel. However, the contra group considered that the Job Creation Law contradicts existing laws, such as not being in line with local governments, especially wages. The law was only centered on the central government, and there was no involvement of local governments in business licensing. The absence of local government involvement in formulating the Job Creation Bill has violated the legal mechanism informal regulations. It can be said to have violated the legal constitution. This means that the concept of the Job Creation Law which makes it easier for the bureaucracy and regulations, is not in line, especially with local government. On the other hand, the pro group considered that the overlapping of regulations was only an assumption. The Job Creation Law has accommodated all interests, which include various laws. Meanwhile, for technical regulations, derivative regulations will be made in the form of Government Regulations $(P P)$.

Fifth, the topic of the employment article is very crucial. This is because the Job Creation Law is considered not to pay attention to the welfare of workers. The group against the Job Creation Law is dominated by workers who strongly object to the existence of the Act. According to them, the Job Creation Law does not have a standardized minimum wage because companies can apply the provincial minimum wage (UMP) in each province. In addition, the exemption of outsourcing in various work sectors will threaten the status of permanent employees and threaten to become permanent contract employees. Another discourse presented was the Employment Copyright Act abolishing workers' pension guarantees by looking at the company's ability to provide severance pay or not. The legal basis is used as a pretext for layoffs in the midst of a pandemic. On the other hand, TKA (Foreign Workers) licensing is also burdensome for workers. The reason is that the Job Creation Law provides relaxation of rules for foreign workers, such as not having to have an Indonesian language certificate, which can threaten local workers.

The points conveyed by the contra group became issues that were opposed from the planning, discussion, ratification, and formulation of derivative regulations. The work creation support group brought the discourse that there would be no reduction in 
labor wages, the use of outsourcing would be ideal for companies that could not afford the layoffs. This group also raised the discourse that layoffs in the Job Creation Law would be immediately paid to workers after one month of being laid off. This change is considered a breakthrough that was not regulated in the previous regulations. The wage and severance pay rules that the contra group questioned were considered unreasonable. The number of severance pay for layoffs in the Job Creation Law still has a high value compared to other Asian countries. This means that the points in question will be technically regulated in derivative regulations so that the workers will accommodate those in question. This condition allows workers and companies to increase dialogue that benefits both parties.

Sixth, the topic of demographic utilization. The existence of the Job Creation Law for supporting groups, especially from the government, claims that the Job Creation Law will increase industrialization in each region so that the distribution of industrialization will be evenly distributed. If industrialization has been evenly distributed, then the task of the government to provide jobs and reduce unemployment can be overcome. This is because each region has the potential as a provider of employment, considering that the total population of Indonesia is recorded at 270.2 million in the report from the Central Statistics Agency (BPS) in September 2020 (www.bps.go.id). Through the industrialization mechanism in each region, the government seeks to take advantage of the demographics of Indonesia's growing population as a supporter to support economic growth in absorbing the workforce.

The government's efforts to industrialize in each region are opposed by groups who reject the ratification of the Job Creation Law. This is because the government's industrialization will develop will be carried out more in the oil palm plantation and industrial mining sectors than in the manufacturing industry. Utilization of the demographic aspect with the proliferation of oil palm plantations and mining industries will not create many decent jobs. This means that the demographic bonus in Indonesia only uses the population as cheap labor in the plantation and mining industries.

Seventh, the issue of disinformation. After the ratification of the Job Creation Law, which was filled with mass actions, groups supporting the Job Creation Law developed a discourse that the information circulating in the community prior to the ratification of the Act was indicated to be a hoax because the explanation did not match the government narrative. The lack of information regarding the Articles of the Job Creation Law is why the counter group took action. Support groups consider that it is necessary to increase public outreach so that the public does not consume the emerging issues. The counter group assesses what is in question based on the articles in the law in accordance with the draft downloaded on the government's official website.

Eighth, political issues. The discourse on the rejection of the Job Creation Law was masterminded by political actors who encouraged people to take to the streets, shown by groups supporting the Job Creation Law, especially from politicians. This discourse continues to be displayed to stem the statements of labor groups who question problematic articles. This political issue was used as a weapon to stem the reaction of the workers who took to the streets whom the government's opposition had influenced. This is because there was a very sharp pro and con process in the plenary session of the DPR RI during the ratification of the Job Creation Law. The faction deemed to have rejected the ratification of the Job Creation Law was claimed to be the mastermind behind the demonstration by the workers.

Meanwhile, the group against the Job Creation Law considers that the ratification 
is a political process and a political victory for the supporters of the coalition of parties carrying the government because there is no urgency to be discussed during the Covid19 pandemic. Moreover, community involvement in the discussion process is minimal. The ratification of the law in a pandemic situation is considered full of political interests from the winning political parties. It is used as the basis for companies to carry out layoffs.

Table 1. Contrasting Discourse

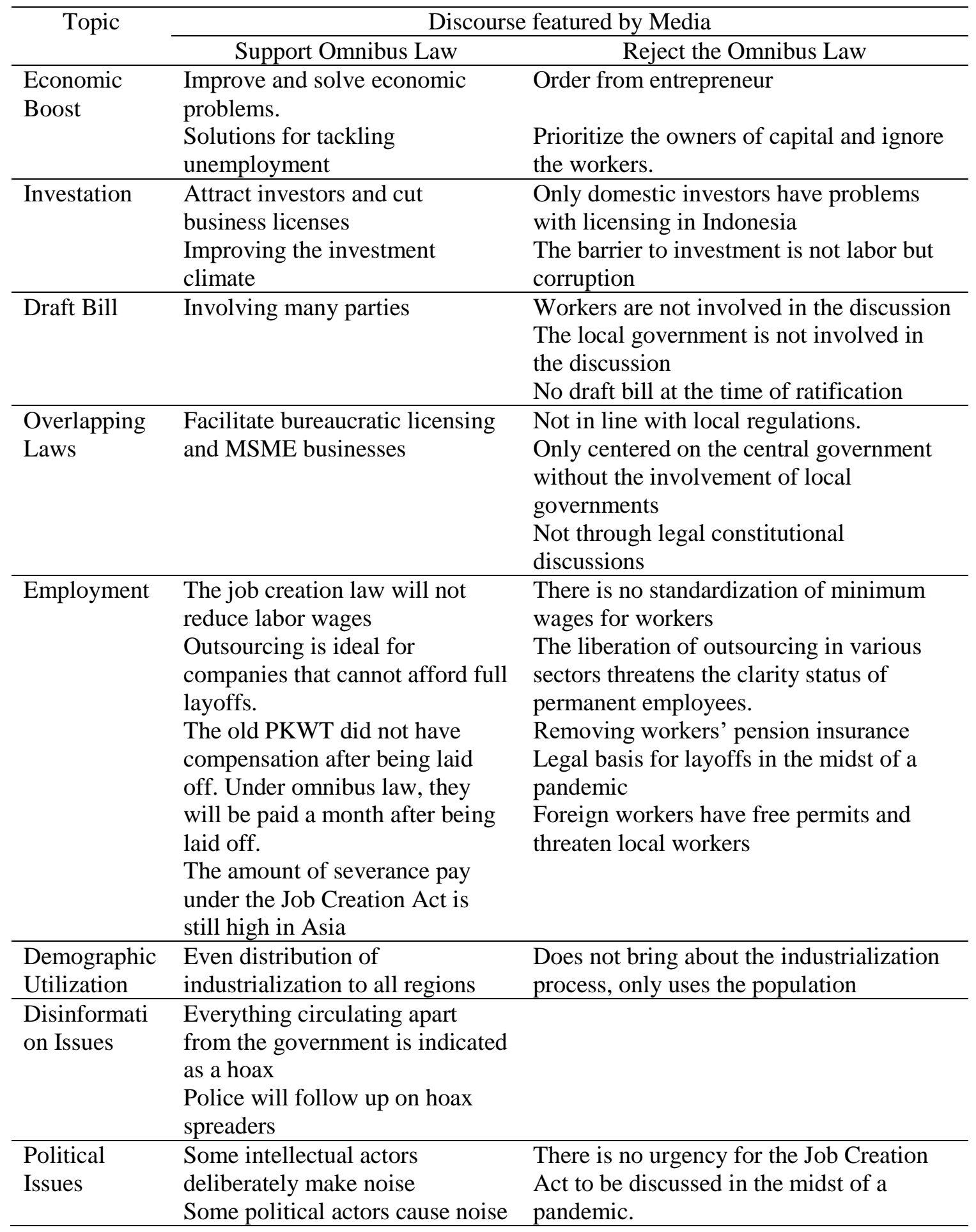


to encourage people to take to the streets
A political process that does not involve workers.

The Job Creation Law is a political victory for the supporters of the large coalition of government parties

The eight topics in the Table above show conflicting discourses that show that business issues are the main problem, followed by a discussion process that does not involve participation and political issues. The Job Creation Law, which covers businesses, raises questions about licensing and employment issues. The issue is assessed from the camp that supports the Job Creation Law as the cause of the slow economy and hinders investment. This means that the Job Creation Act will be able to overcome this. The lack of public participation has become a discourse raised by the contra, which is based on a process of drafting and discussing a lack of openness. There is a tendency for the process to be accelerated, and there is no urgency to be discussed in a pandemic situation, a discourse that always gets opposition. Meanwhile, Political issues were discussed by parties who support the Job Creation Law in response to the widespread mass action against the Job Creation Law in each region. This accusation was made with discourses of mass action ridden by the opposition. Misinformation and disinformation are relevant because they can influence citizens' perceptions of false realities and political evaluations (Hameleers \& Minihold, 2020). This means that this step is used to assess the public's negative discourse on the Articles of Job Creation shifts towards mass action consumed by fake news. The four media tend to display contradictions about the Job Creation Law compared to mediation efforts that provide justice for both groups. The issue of conflict has left groups opposed to the Job Creation Act having less space and experiencing pressure from various parties.

\section{Media in the Vortex of the Employment Creation Act}

The eight issues of discourse on the Job Creation Act, which were packaged by television media, did not balance the news delivery process. The tendency of the discourse to support the Job Creation Law is very clear from the duration, selection of sources, and the themes of the event. The existence of a fairly large discourse contradiction in the media, especially television media, is not matched by the same space from groups that oppose it. The four television stations tend to report the Job Creation Act $(60 \%)$ positively. Not much space is given to groups that reject job creation; the percentage is $32 \%$. Meanwhile, for neutral statements, only $8 \%$ of the total duration of the show. Metro TV has become a media that strongly supports reporting on the Job Creation Act.

These findings indicate that television shows a supportive attitude towards the Job Creation Law than online media. According to a study of www.remotivi.or.id, (2020), online media reported positive as much as $52.58 \%$, negative $16.43 \%$, and neutral $31.58 \%$. This means that the four television stations provided space for support to the government. This tendency shows that the media in Indonesia is more of a means of conveying plans to introduce or socialize programs rather than providing information and mediation for opposing groups. Meanwhile, the findings regarding the narrative of a lack of socialization which was later referred to as a procedurally flawed law, are in line with the findings(Febriansyah \& Muksin, 2021), who said that the low level of socialization led to the emergence of hoaxes on social media. Furthermore, Referring to 
Korniawan's (2019) study, the discourse on the government's plan to collect taxes from the e-commerce business was informative and supportive. This has similarities with the discourse on the Job Creation Law which provides more informative and supportive aspects.

The media tend to support the government's interests, compared to the community's interests. The media's mediation efforts in overcoming several laws issued in the Job Creation Law have various records that are considered detrimental but are not appropriately channeled. The aggrieved parties, such as workers, consider that the law has problems involving labor, indigenous peoples, and the environment. Indications of political interests between business people and the government are not appropriately mediated. StudiesKovalev (2020)stated that the media experienced direct intervention by the authorities in censorship on sensitive topics, such as foreign issues, domestic policies, and mass opposition protests. The media make news for the benefit of the market. This means that there is a change in viewing the issue, namely that the media is not a critical public space but a business tool for certain groups in securing positions.

Meanwhile, crucial issues concerning the community's welfare are not specifically broadcast or displayed by the media. The media only provides a portion of the news that brings in many sources from the government with normative statements to answer issues circulating in the community. The imbalance in media coverage can be seen from the composition of the speakers displayed. In detail, the groups that support the Job Creation Law are more dominantly displayed by the media compared to groups that are against the Job Creation Law. According to Balkin (1999), television tends to turn legal and political coverage into entertainment for mass consumption. Limited broadcast time and audience attention, making stories about political strategy, political infighting, political scandals, and personal life, making stories about substantive policies covered up because they are less interesting. In the end, entertainment dominates and excludes the forms of political information and public discussion that distort the meaning of true discourse. This fact makes the substance of the Job Creation Law cover up with the actions of the speakers who shape the discourse through public discussion. Actors will play a role so that the constructed discourse can be accepted. This can be seen in Figure 1, which shows that actors favor the Job Creation Law by $60 \%$, compared to $32 \%$.

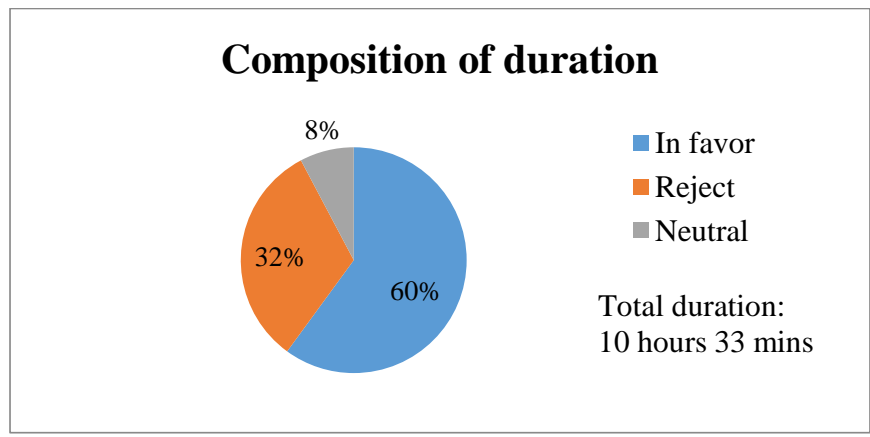

Figure 1. Talk Time Duration of Pros and Cons

The duration of speaking time on television is a minimal and valuable opportunity. The limited-time and nature of broadcasts that cannot be repeated give television the authority to determine who is entitled to a place. The selection of source persons is closely related to the background and interests of the editor. Metro TV stations (81\%), 
Kompas TV (66\%), and TV One (52\%) have the highest percentage of exposure to supporters of the Job Creation Law compared to groups who reject or will be disadvantaged by the law. Meanwhile, CNN Indonesia (29\%) is the only media with a low percentage of exposure to supporters of the Job Creation Law. This shows that the three media tend to act as media to support the government's interests in the polemic of the Job Creation Law. Politically, the three media tend to have close ties to the government. Metro TV provides support for the government, which cannot be separated from ownership. This is in line with the findings by Remotivi.or.id (2020), Media Indonesia, which is in the same group as Metro TV, was the most positive in reporting the Job Creation Act. However, something different was found in Kompas TV's news coverage, which showed more positive support than Kompas.com. TV One station has a high percentage of reporting support for the Job Creation Law.

Meanwhile, CNN Indonesia, one of the media subsidiaries owned by Trans Corp, showed different results. The exposure of groups who reject the Job Creation Law is shown more than the groups that support it. CNN Indonesia performed $43 \%$ rejecting and being the highest among the three previous media, namely Metro TV (19\%), Kompas TV (34\%), and TV One (38\%). This shows that CNN Indonesia tends to present groups that refuse to ratify the Job Creation Law. Politically, CNN Indonesia or Trans Corp is a media that tends to side with the government's opposition. Media systems in developing countries tend to be centered on cross-ownership, centered on projected influence, and conglomerate business synergies. This causes media ownership as a way of creating political influence(Chadha, 2017; Noam, 2018). The four media are likely to have a high interest in the Job Creation Law. This can be seen from ownership and the issue of labor articles which have been a problem in the world of work in the media, such as living wages and job security.

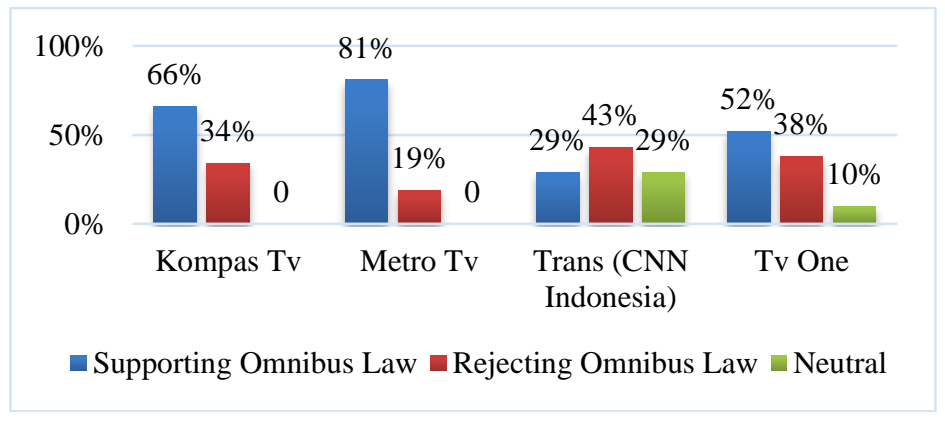

Figure 2. The Duration of the Source Persons' Talks in Each Television Media

In addition to the imbalance in duration, the media also provides a bigger stage for sources who support the Job Creation Law. The resource persons from the groups supporting the Job Creation Law presented were quite diverse who came from a homogeneous environment and had the same interests, namely the government (23\%), parliament (21\%), and businessmen (12\%). Meanwhile, groups that are against the Job Creation Law are not widely represented and come from a heterogeneous environment, namely workers $(15 \%)$, academics $(15 \%)$, and the general public $(6 \%)$. This shows that the diversity of sources from groups against the Job Creation Law is not widely displayed by the media. The media only provides such a large space for groups interested in the ratification of the Job Creation Law. In raising political issues, the media only becomes an explanation of the discourse raised by the political elite 
(government), not as a discourse determinant that provides a neutral space for conflicting discourses (Dekavalla, 2018).

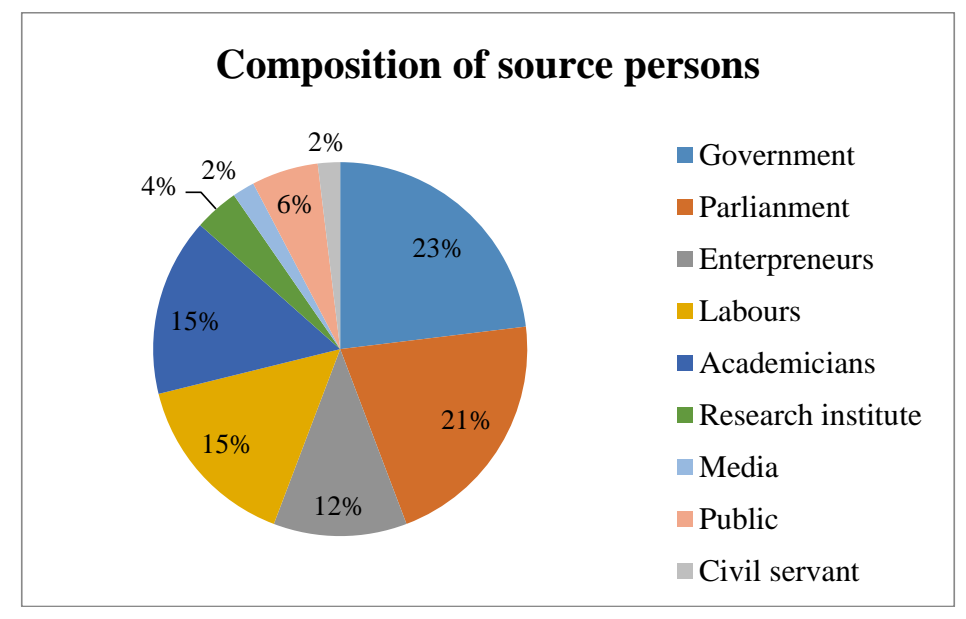

Figure 3. Composition/Background of Source Persons

Research results that take into account the composition of sources presented by the media have two indications. First, Figure 4 shows the percentage of respondents who have positive sentiments, dominated by the government (37\%), parliament (23\%), and businessmen (20\%). Meanwhile, other actors are used as supporting and complementary tools for the interests of the government agenda, namely the state apparatus (3\%), the media (3\%), the general public (7\%), and research institutions (4\%). The Job Creation Act is a program scheduled by the government. Sources from the government and parliament have a strong influence in providing support discourse. The government, as the executor, wants the Job Creation Act to be ratified immediately. Parliament's support for the ratification of the Job Creation Law is inseparable from the background of the members of parliament (koran.tempo.co, 2020). This is reinforced by the discourse that is often displayed by the media, which has a high tendency to discuss business issues (investment, employment, and licensing) rather than administrative issues.

According to Altheide and Snow (1979:10), media logic is how the media present and disseminate information. It concerns how the material is arranged, the style of the material is focused or emphasizes certain characteristics of behavior, and the grammar of media communication. The framework is used to interpret phenomena (Habler, Maurer, \& Oschatz, 2014). The logic of the media makes the Job Creation Law regulated. The discourses that are always raised by speakers with positive sentiments are in the form of improving the investment climate and improving the country's economy. The creation of the Job Creation Law is the government's effort to tackle unemployment and poverty, which are currently crucial problems in Indonesia. In addition to the discourse on improving the economy and investment, groups supporting the Job Creation Law are very active in promoting the discourse that the mass action carried out by the workers is an action that was deliberately masterminded by political actors by spreading disinformation about articles that are considered problematic. The dominance of government actors in media sources shows that television cannot be separated from the influence of the government. It turns out that media that are 
considered independent are not entirely independent. The media will always take a certain position in covering a political figure. A media will give more space to political figures or candidates and not to others (Khotimah, 2019).

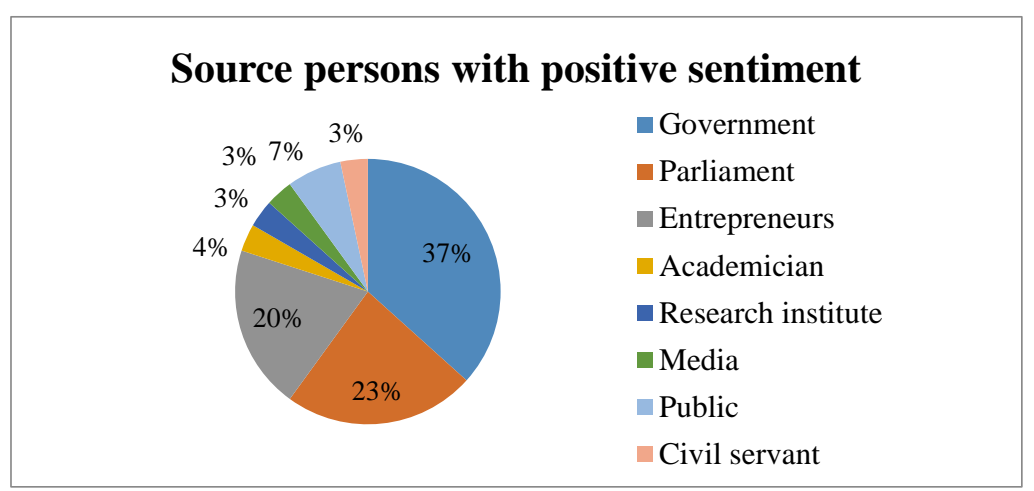

Figure 4. Resource Persons Have a Positive Sentiment

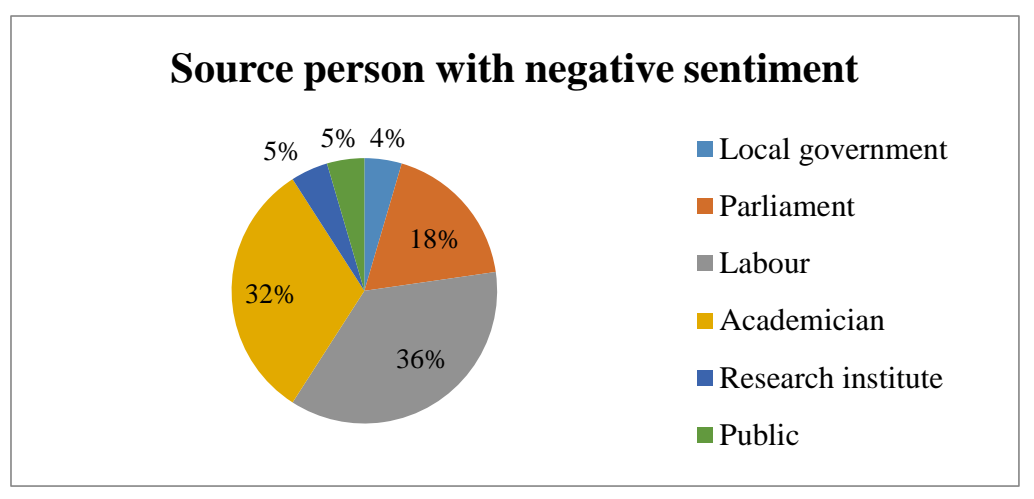

Figure 5. Resource Persons with Negative Sentiment

Second, Figure 5 shows the percentage of sources with negative sentiments coming from different groups, namely workers (36\%), academics (32\%), opposition parliaments (18\%), local governments (4\%), research institutions (5\%), and the general public (5\%). The diversity of groups with negative sentiments is based on various criticisms of the Job Creation Act, which can harm workers and other aspects. There are various discourses raised by sources who have negative sentiments to reject the ratification of the Job Creation Law. For instance, there is no government transparency in preparing the bill of Employment Creation Law. The bill to be ratified has various problems that can harm workers and endanger the environment and indigenous peoples. The bill of job creation law is considered to violate the constitution because it does not involve local governments and only focuses on the central government. It becomes a tool for the interests of entrepreneurs through the government. The process of administrative problems is highly emphasized by the media to counter actors in covering up substance issues. This can be seen from academic actors who have the second-highest percentage. Workers as parties who feel aggrieved consider the Job Creation Law to have procedural defects that do not protect workers' rights. Meanwhile, the contra parliament considered that the ratification process was too hasty and did not involve many parties in its formulation. 
Sources for research institutions focused more on the environmental impacts caused by the existence of the Job Creation Law. Community responses tend to comment on actions rather than substance. This means that the issue of political action raised by the support group about the action of rejection in the field can divert people's attention to the content. Only workers and research institutions consider the Job Creation Law to be a threat rather than an advantage. The media's move to discuss the administrative issues of the Job Creation Act was able to suppress the critical opinion of academics about the threat to the substance of the Job Creation Act. It seems that the political actors presented by the media are in line with the logic of the media. The placement of actors with positive sentiments is more voicing the political agenda, and actors with negative sentiments respond to the problems that arise. Media as the mediator has their role reduced.

One of the functions of mass communication, namely the supervisory function, involves instrumental surveillance (Dominick, 2011:32). This function requires mass communication as an instrument to convey or disseminate information that can help the community. What the four television stations do has differences in carrying out the function of mass communication. Metro TV, Kompas, and TV One provide more room for support for the Job Creation Law, which means that they have not carried out their functions in a balanced manner. The media focuses more on the voices of the government elite, who may have more reach on the media. As a result, the community's discussion space is limited. The data shows that the broader space for elites ultimately provides wider opportunities for elite discourse to support their interests, such as business issues, disinformation, and political action. As a result, society consumes information that is not balanced. Seeing that only CNN Indonesia provides space for the contra group, the main problem is the condition of the media in Indonesia which only sided with the ruling group rather than providing proper and balanced information to the audiences.

The supervisory function is interpreted by the four television stations to monitor the government's agenda and suppress the interests of counter groups. The idealism of the media, which should present various perspectives in a balanced way, in fact, does not work by prioritizing independence. The role of the media, which should be a social control force in overseeing government policies, is not fully implemented. The authorities' approach to the media creates bias so that the function of the media as a tool to criticize government policies loses power and influence. People or disadvantaged groups do not have a stage to voice their interests, especially on television.

\section{Conclusion}

Disputes about the work creation law on four television stations show more positive sentiments towards this law. The space for resource persons who provide support is much greater than resource persons who provide refusal. This is indicated by the duration of the talk, the actors displayed and the agenda brought by each actor. The discourse presented by the media in reporting the Job Creation Law focuses more on labor issues and the investment climate. It does not present other equally crucial discourses, such as environmental issues, indigenous peoples, changes to the Press Law, and other laws that are considered detrimental to all sectors. The choice of topic in determining the discourse reflects the reality chosen by the media in accordance with the ideological standards of the media organization. The media has not yet fully provided a vast space to mediate between the pro and contra groups because the data 
shows that the four television stations have taken sides with the support for the Job Creation Law in setting the agenda, sources, and duration. The media prefers to present the reality of public debates rather than discuss the substance of the law being debated and follow the flow of the narrative presented by the main sources, especially the government. The data shows that the mass media functions more to socialize the government's version of the Job Creation Law rather than as a deliberative discussion space between the state and the public. As a result, the function of the mass media as an instrument of supervision is limited by the influence from outside the editorship that affects the content and critical space of the media as a means of maintaining debate rather than providing solutions to problems.

Television as a medium that functions as a disseminator of knowledge and information has indeed taken place with the appearance of this work creation law in a television dialogue program. However, the kind of knowledge and information disseminated is the material criticized in this paper. In fact, the information flows more from the top-down or the elite to the public and not bottom-up or from the public to the elite. This study suggests that television should be more sensitive in raising issues that are currently a problem for the public by providing a more comprehensive public voice than socializing and confirming the government's agenda. The diversity of sources and the diversity of issues are the major keys in producing a media agenda that is not only pro-public but also includes political education for the wider community.

\section{References}

Ayish, MI (2002). Political communication on Arab world television: Evolving patterns. Political Communication, 19(2), 137-154. https://doi.org/10.1080/10584600252907416

Balkin, JM (1999). How mass media simulate political transparency. Cultural Values, 3(4), 393-413. https://doi.org/10.1080/14797589909367175

Catrina. (2014). The Influence of Media Owner's Political Orientation on Television News.

Chadha, K. (2017). The Indian news media industry: Structural trends and journalistic implications. Global Media and Communication, 13(2), 139-156. https://doi.org/10.1177/1742766517704674

Dekavalla, M. (2018). Issue and game frames in the news: Frame-building factors in television coverage of the 2014 Scottish independence referendum. Journalism, 19(11), 1588-1607. https://doi.org/10.1177/1464884916674231

Dominick, JR (2011). The dynamics of mass communication: media in transition.

Fairclough, N. (1995). Critical Discourse Analysis: The Critical Study of Language. London and New York: Longman.

Febriansyah, F., \& Muksin, NN (2021). Hoax Distribution in Social Media after Ratification of Omnibus Law. Jurnal ASPIKOM, 6(2), 315. https://doi.org/10.24329/aspikom.v6i2.871

Habler, J., Maurer, M., \& Oschatz, C. (2014). Media Logic and Political Logic Online and Offline. Journalism Practice, 8(3), 326-341. https://doi.org/10.1080/17512786.2014.889451

Hajad, V. (2018). Media And Politics (Seeking Media Independence in Political News). Source: Journal of Communication Studies, 2(2), 1-10. https://doi.org/10.35308/source.v2i2.295

Hameleers, M., \& Minihold, S. (2020). Constructing Discourses on (Un)truthfulness: 
Attributions of Reality, Misinformation, and Disinformation by Politicians in a Comparative Social Media Setting. Communication Research, 1-24. https://doi.org/10.1177/0093650220982762

Hantoro, NM (2019). Parliamentary Review OMNIBUS LAW. Parliamentary Review, l(1), 1-9.

Hutchby, I. (2019). Conversation Analysis. (September).

Khotimah, N. (2019). Challenges of Media Independence in Elections: The Case of Kompas.Com. Islamic Communication Journal, 4(2), 133-145.

Korniawan, R. (2019). Media Discourse Analysis of E-Commerce Tax Policy Plan Reporting. Journal of Development Communication, 17(1), 86-91. https://doi.org/10.29244/jurnalkmp.17.1.86-91

Kovalev, A. (2020). The political economics of news making in Russian media: Ownership, clickbait and censorship. Journalism, 1-13. https://doi.org/10.1177/1464884920941964

Matompo, OS, \& Izziyana, W. Vivid. (2020). The Omnibus Law Concept and the Problem of the Job Creation Bill. Rechstaat Nieuw (New Rule of Law), 5(1), 2229.

Morissan. (2015). Theory of Individual to Mass Communication. Jakarta: Kencana.

Musfialdy, M. (2019). Media Independence: Pros and Cons of Objectivity and Neutrality of Media Reporting. Journal of Communication Research, 2(1), 21-28. https://doi.org/10.24329/jurkom.v2i1.50

Nasrulah, R. (2020). Journalism Research Methods Qualitative Approach. Bandung: Symbiosis Rekatama Media.

Noam, E. (2018). Beyond the mogul: From media conglomerates to media portfolio. Journalism, 19(8), 1096-1130. https://doi.org/10.1177/1464884917725941

Businessmen Occupy Almost Half of Parliament - Headline News newspaper.tempo.co. (nd).

Putra, A. (2020). Application of Omnibus Law in Regulatory Reform Efforts. Indonesian Legislation Journal, 17(12), 1-10.

Santosa, BA (2017). The Role of Mass Media in Preventing Conflict. Jurnal ASPIKOM, $3(2), 199-214$.

Toruan, HDL (2017). Establishment of Business Entity Regulations Using the Omnibus Law Model. To-Ra Journal of Law, 3(1), 463-473.

Woffitt, R. (2005). Conversation Analysis \& Discourse Analysis. London: SAGE Publications Ltd.

Wulandari, TD (2016). Jokowi-Jusuf Kalla Government According to the Eyes of 5 Mass Media in Indonesia. Jurnal ASPIKOM, 3(1), 88. https://doi.org/10.24329/aspikom.v3i1.102

Www.remotivi.or.id. (2020). Omnibus Law: Media Becomes Government Public Relations - Remotivi. 